\title{
Characterization of falls in adults with established rheumatoid arthritis and associated factors
}

\author{
Mariana de Almeida Lourenço*, Flávia Vilas Boas Ortiz Carli and Marcos Renato de Assis
}

\begin{abstract}
Background: Rheumatoid arthritis patients may have an increased risk of falls due to changes caused by the disease such as muscle weakness, joint impairment, reduced mobility and postural instability. The aim of this study was to prospectively analyze the occurrence of falls in RA patients and its risk factors.

Methods: A cohort of 86 RA patients were assessed over 1 year for disease activity using the Disease Activity Score (DAS-28), for functionality using the Health Assessment Questionnaire (HAQ), for the characterization of falls and for the use of medications, and they were subjected to the Berg Balance Scale (Berg), Timed Up and Go (TUG), 6Minute Walk (6MWT) and Short Physical Performance Battery (SPPB) tests. The Kolmogorov-Smirnov, Spearman's correlation, Student's t, Mann-Whitney and chi-square tests were performed with a significance level of $P \leq 0.05$.

Results: A total of 86 patients were evaluated, of which $48.8 \%$ had at least one fall and $75.6 \%$ reported having a fear of falling. No association of falls with age, disease duration, functional capacity, disease activity or physical performance was found. Patients with poorer performance in the physical tests had more functional impairment, higher disease activity and more advanced age. No differences in physical or functional performance, disease activity, gender or fear of falling were found between fallers and non-fallers; only a greater amount of medications used was found in the group of fallers.
\end{abstract}

Conclusions: The occurrence of falls was high and associated with a previous history of falls and polypharmacy, with no association with disease activity or duration, functional capacity, physical performance, age or gender.

Keywords: Postural balance, Physical aptitude, Rheumatoid arthritis, Accidental falls

\section{Background}

Falls have a multifactorial etiology in the elderly, mainly due to intrinsic factors such as decreased muscle strength, balance deficits, and gait pattern changes. These age-related changes can also be observed in other diseases [1-3].

Rheumatoid arthritis (RA) is a chronic systemic inflammatory autoimmune disease of joint predominance, with a high prevalence of falls occurring in 14.3 to $54 \%$ of patients over a one-year period, which are high values compared to the general population [4-19]. This increased risk of falls may be due to pain, edema, deformities, loss of muscle strength or gait changes, and

\footnotetext{
* Correspondence: maalmeida1@terra.com.br

Marília School of Medicine, R. Pedro Martins, 209. Marília/SP - Brazil, Marília, São Paulo CEP 17519-430, Brazil
}

prospective studies have shown associations with altered balance, use of psychotropic medications, fear of falling and previous falls [4-8]. However, findings regarding several other risk factors, the characterization of falls and the consequences of falls in RA patients are still scarce or contradictory.

The aim of this study was to prospectively analyze the occurrence of falls in RA patients for 1 year and to investigate whether physical fitness and balance tests, medication use, previous history of falls, disease activity and functionality are associated with falls.

\section{Methods \\ Sample}

A prospective study based on the sample of a previous retrospective study composed of 99 patients diagnosed 
with RA was conducted at the Rheumatology outpatient clinic of the Marília School of Medicine [19, 20].

Adults with a diagnosis of RA according to the American College of Rheumatology (ACR) classification criteria of 1987 and/or the 2010 ACR/EULAR (European League Against Rheumatism) RA classification criteria were included [21]. Patients with cognitive impairments precluding them from answering the questionnaires, using a wheelchair or with other physical disabilities that impeded the execution of the tests were excluded.

The study was approved by the Research Ethics Committee of the Marília School of Medicine, protocol CAAE: 22845513.3.0000.5413. All participants signed the informed consent form.

\section{Procedure}

The rheumatologist confirmed the RA diagnosis and performed the measurements to assess disease activity, and the nurse collected the blood samples. Next, the anthropometric data were measured, and the functional questionnaires and physical tests were applied by the nurse and the physical therapist.

From the initial evaluation, the patients were followed up for 1 year by quarterly telephone contact to record the occurrence of falls and their characteristics. After 12 months, the disease activity and functionality assessments and physical tests were repeated.

\section{Instruments}

Patients were assessed for disease activity using the Disease Activity Score (DAS-28) [21], for functional capacity using the Health Assessment Questionnaire (HAQ) $[22,23]$ and for the occurrence of falls using a fall characterization questionnaire $[19,20]$.

The following physical tests were performed:

The Berg Balance Scale was used to determine risk factors for loss of independence and falls in the elderly. The scale has 14 items common to daily life, scored from 0 to 4, with a higher fall risk associated with lower scores. The predictive value of falls in the elderly ranges from 45 to 48 [24-27].

The Short Physical Performance Battery (SPPB) was used to assess standing balance, walking ability and sit-to-stand performance. The three items are scored from 0 to 4 , with poorer physical function associated with lower scores. Standing balance is evaluated in three positions with progressive difficulty - feet together, with the hallux leaning against the medial edge of the opposite heel and with the hallux leaning against the posterior edge of the opposite heel. Walking is evaluated by measuring time, in seconds, for a distance of four meters. In the sit-to-stand evaluation using a chair, the action is performed five times with the arms crossed in front of the chest, and time is also recorded in seconds $[28,29]$.

The Timed Up and Go Test (TUG) was used to assess body balance and risk of falls, especially in the elderly. The test begins with the patient sitting on a chair, then getting up, walking a three-meter distance, making a $180^{\circ}$ turn, returning and sitting on the same chair. The different lengths of time spent indicate the following: $\leq 10 \mathrm{~s}$ - elderly without balance alteration and with low risk of falls; between 10 and $20 \mathrm{~s}$ - elderly with no significant balance alteration but presenting some weakness and medium risk of falls; and $\geq 20 \mathrm{~s}$ - elderly with a high risk of falls [30]. Other studies consider a higher risk of falls between 10 and $14 \mathrm{~s}$ [24, 31, 32].

The 6-Minute Walk Test (6MWT) was used to assess functional capacity and exercise tolerance through the distance an individual is able to walk on a hard, flat surface for $6 \mathrm{~min}$. In healthy adults, the reference values are $580 \mathrm{~m}$ for men and $500 \mathrm{~m}$ for women [33, 34].

\section{Statistical analysis}

The Kolmogorov-Smirnov (KS) test was used to evaluate the normality of the data distribution. Values were expressed as the mean and standard deviation (SD) for variables with normal distribution and as the median and percentages for the others. Correlations were analyzed using Spearman's test, and other analyses were conducted using Student's t-test, the Mann-Whitney U-test and chi-square tests with a significance level of $p<0.05$. The statistical program used was SPSS v.21 (IBM Armonk, NY, USA, 2012).

\section{Results}

A total of 99 patients were included in the study, but 13 were lost - three died, three had medical follow-up unit changes, three were not found, two were bedridden, one refused to participate, and one suffered an ankle sprain - leaving 86 patients. The majority of the sample consisted of white married women with a mean age of $55 \pm$ 11.8 years (Table 1 ).

There were 67 fall episodes in the one-year follow-up period; $48.8 \%$ of these patients fell at least once, and $75.6 \%$ reported the fear of experiencing a fall episode. Falls occurred most often at home (58.2\%), in the morning $(41.8 \%)$, while the patients walked $(65.7 \%)$ and due to tripping and slipping (65.5\%), and fracture occurred in three falls (4.4\% of the total).

No association was found between the number of falls and age, disease duration, functional capacity, disease activity or physical performance. Patients with poorer performance on the physical tests had more functional impairment, higher disease activity and advanced age. The higher disease activity was associated with poorer 
Table 1 Characteristics of the sample of patients with rheumatoid arthritis

\begin{tabular}{|c|c|c|}
\hline Participants, n & & 86 \\
\hline Women, n (\%) & & $76(88.4)$ \\
\hline Age (years), mean \pm SD (min-max) & & $55 \pm 11.8(23-88)$ \\
\hline BMI $\left(\mathrm{kg} / \mathrm{m}^{2}\right)$, mean $\pm \mathrm{SD}($ min-max $)$ & & $27.7 \pm 5.3(15.35-40.04)$ \\
\hline Self-reported ethnicity, n (\%) & White & $54(62.8)$ \\
\hline & Mixed & $20(23.3)$ \\
\hline & Black & $12(14)$ \\
\hline Marital status, n (\%) & Married & $52(62.8)$ \\
\hline & Single & $14(16.3)$ \\
\hline & Divorced & $10(11.6)$ \\
\hline & Widowed & $8(9.3)$ \\
\hline Duration of disease (years), median (P25-75) (min-max) & & $10(5-16.5) ;(2-40)$ \\
\hline Self-reported associated diseases (\%) & $\mathrm{HBP}$ & 53.5 \\
\hline & Osteoporosis & 17.4 \\
\hline & $\mathrm{DM}$ & 12.6 \\
\hline & Labyrinthitis & 11.6 \\
\hline & $\mathrm{HF}$ & 8.1 \\
\hline & Fibromyalgia & 7.0 \\
\hline & Hypothyroidism & 7.0 \\
\hline & Depression & 3.4 \\
\hline Falls in the previous year (\%) & & 37.4 \\
\hline Walking aids (\%) & & 9.3 \\
\hline
\end{tabular}

n: number; \%: percentage; SD: standard deviation; min: minimum; max: maximum; BMI: body mass index; kg: kilogram; $\mathrm{m}^{2}$ : square meter; P25-75: 25th percentile and 75th percentile; HBP: high blood pressure; DM: diabetes mellitus; HF: heart failure

physical performance, poorer functional capacity and longer disease duration (Table 2).

There was no significant difference in functional capacity or disease activity in the initial evaluation and after 1 year. However, in the physical tests, better performance was observed in the final evaluation when compared to the initial evaluation (Table 3).

When divided into groups according to the occurrence of falls, considering fallers as patients with at least one fall episode during the follow-up period, no significant differences were found between fallers and non-fallers regarding physical or functional performance, disease activity, gender or fear of falling (Tables 4 and 5). The number of medications used and history of falls differed significantly between fallers and non-fallers (Table 5).

\section{Discussion}

The incidence of falls in this sample of RA patients was high $(48.8 \%)$ compared to that found in the literature, which shows ranges from 14.3 to $54 \%$ in retrospective studies and from 18.8 to $50 \%$ in prospective studies $[4-9,11-19]$. The incidence of falls

Table 2 Correlations between the number of falls with clinical variables and functional tests

\begin{tabular}{lllll}
\hline & Number of falls, $r(P)$ & Age, $r(P)$ & HAQ, $r(P)$ & DAS28, $r(P)$ \\
\hline Age & $0.059(0.592)$ & - & $-0.109(0.317)$ & $0.034(0.755)$ \\
RA duration & $-0.077(0.483)$ & $0.187(0.087)$ & $0.066(0.550)$ & $0.224(0.039)^{*}$ \\
HAQ & $0.151(0.165)$ & $-0.109(0.317)$ & - & $0.468(0.000)^{*}$ \\
DAS28 & $0.004(0.973)$ & $0.034(0.755)$ & $0.468(0.000)^{*}$ & - \\
Berg & $-0.127(0.244)$ & $-0.367(0.001)^{*}$ & $-0.541(0.000)^{*}$ & $-0.422(0.000)^{*}$ \\
6MWT & $-0.124(0.260)$ & $-0.244(0.024)^{*}$ & $-0.495(0.000)^{*}$ & $-0.294(0.006)^{*}$ \\
TUG & $0.064(0.558)$ & $0.243(0.025)^{*}$ & $0.557(0.000)^{*}$ & $0.363(0.001)^{*}$ \\
SPPB & $-0.121(0.266)$ & $-0.291(0.007)^{*}$ & $-0.658(0.000)^{*}$ & $-0.404(0.000)^{*}$ \\
\hline RA:
\end{tabular}

RA: rheumatoid arthritis; HAQ: Health Assessment Questionnaire; DAS28: Disease Activity Score 28; Berg: Berg Balance Scale; 6MWT: 6-min walk test; TUG: Timed Up and Go; SPPB: Short Physical Performance Battery; r: Spearman's correlation; P: significance level 
Table $\mathbf{3}$ Initial and final scores on physical, functional and disease activity tests

\begin{tabular}{llll}
\hline & Initial & Final & P \\
\hline HAQ, median (P25-75) & $0.62(0.12-1.25)$ & $0.62(0.12-1.37)$ & 0.318 \\
DAS28, mean ( \pm SD) & $3.40( \pm 1.17)$ & $3.58( \pm 1.32)$ & 0.215 \\
6MWT (meters), mean ( \pm SD) & $391.27( \pm 103.78)$ & $429.52( \pm 129.01)$ & 0.001 \\
Berg, median (P25-75) & $53(49.75-56)$ & $55(50.75-56)$ & 0.019 \\
TUG (seconds), median (P25-75) & $8.89(7.59-11.69)$ & $8.75(7.14-11.28)$ & 0.071 \\
SPPB, median (P25-75) & $10(8-12)$ & $11(9-12)$ & 0.001 \\
\hline
\end{tabular}

HAQ: Health Assessment Questionnaire; DAS28: Disease Activity Score 28; 6MWT: 6-min walk test; Berg: Berg Balance Scale; TUG: Timed Up and Go; SPPB: Short Physical Performance Battery; P25-75: 25th percentile and 75th percentile; SD: standard deviation; P: t test significance level

observed was also high compared to that of noninstitutionalized elderly individuals, which ranges from 15.9 to $56.3 \%$ [2]. Although age is an important risk factor for falls, the association between falls and advanced age was not observed in this sample, which is in agreement with previous RA studies [4-6, 12, 15, 35].

Comparing fallers with non-fallers, there was again agreement with other RA studies but a difference from what occurs in the elderly - there was no predominance of falls among females. It is possible that no difference was observed between men and women because both genders have decreased muscle mass and similar patterns of medication consumption [5-7, 15, 35].

The use of several medications may increase the occurrence of falls due to interactions between medications or their side effects. In the present study, we found a significant difference between fallers and non-fallers in relation to polypharmacy. Armstrong et al. [15] reported an association between a higher number of medications and a higher risk of falling, while Stanmore et al. [36] found that using four or more medications more than doubles the risk of falling in RA patients. An association has also been found between falls and the use of medications such as antihypertensives, diuretics, sedatives, antidepressants and antipsychotics $[6,8,15,36-39]$.

Table 4 Differences between disease activity and physical and functional performance in fallers and non-fallers

\begin{tabular}{lllll}
\hline & Fallers $(n=42)$ & Non-fallers $(n=44)$ & Test & $P$ \\
\hline HAQ & $0.81(0.22-1.75)$ & $0.50(0.12-1.34)$ & $\mathrm{U}=763.5$ & 0.164 \\
DAS28 & $3.70( \pm 1.49)$ & $3.47( \pm 1.16)$ & $t=-0.798$ & 0.427 \\
6MWT & $376.31( \pm 100.74)$ & $405.88( \pm 105.79)$ & $t=1.320$ & 0.190 \\
Berg & $53(47.75-55.25)$ & $54.5(50-56)$ & $\mathrm{U}=787$ & 0.229 \\
TUG & $9.27(7.89-11.62)$ & $8.73(7.35-12.08)$ & $\mathrm{U}=852$ & 0.660 \\
SPPB & $10(7.75-11)$ & $10.5(9-12)$ & $\mathrm{U}=784.5$ & 0.219
\end{tabular}

HAQ: Health Assessment Questionnaire; DAS28: Disease Activity Score 28; 6MWT: 6-min walk test; Berg: Berg Balance Scale; TUG: Timed Up and Go; SPPB: Short Physical Performance Battery; P: significance level; $t: t$ test; $U$ : Mann-Whitney U-test

Values are expressed as the mean ( \pm standard deviation) or median (25th 75th percentile)
The history of falls was associated with the occurrence of new falls, which indicates the need for special attention in the evaluation of RA patients who have already fallen $[4,6,7,36]$.

Most of the sample presented moderate disease activity, which, similar to the study by Bohler et al. [12], was associated with poorer performance in most physical tests, but not the occurrence of falls. Koerich et al. [40] argued that the level of disease activity may influence physical performance (Berg and TUG), suggesting an increased risk of falling or dependence in performing activities of daily life. The lack of association between poor physical performance and disease activity with the presence of falls may be related to the time of evaluation, which usually occurs at the beginning or end of the study and not at the time of the falls. Another reasonable explanation is that the increased disease activity results in restriction of activities and therefore reduces the individuals' exposure to situations with a risk of falls.

Other studies have indicated functional disability as a risk factor for falls, but in our study, although it was associated with poorer performance in physical tests, it was not correlated with falls $[4,9,12,13,19,20,35]$. In a prospective study with 80 patients in Japan, Hayashibara et al. [6] found no relationship between functional disability and the presence of falls and explained that the

Table 5 Differences between number of medications, history of falls, gender and fear of falling between fallers and non-fallers

\begin{tabular}{|c|c|c|c|c|c|}
\hline & & \multicolumn{2}{|c|}{$\begin{array}{l}\text { Occurrence } \\
\text { of falls }(n)\end{array}$} & \multirow[b]{2}{*}{$x^{2}$} & \multirow[b]{2}{*}{$P$} \\
\hline & & No & Yes & & \\
\hline \multirow[t]{2}{*}{ Polypharmacy } & Up to three medications & 20 & 9 & 5.55 & 0.018 \\
\hline & Four or more & 24 & 33 & & \\
\hline \multirow[t]{2}{*}{ History of falls } & Yes & 10 & 22 & 8.087 & 0.004 \\
\hline & No & 34 & 20 & & \\
\hline \multirow[t]{2}{*}{ Gender } & Female & 38 & 38 & 0.354 & 0.552 \\
\hline & Male & 6 & 4 & & \\
\hline \multirow[t]{2}{*}{ Fear of falling } & Present & 31 & 31 & 0.120 & 0.729 \\
\hline & Absent & 13 & 11 & & \\
\hline
\end{tabular}

$\mathrm{X}^{2}$ : chi-square; $\mathrm{P}$ : significance level 
findings were due to the fact that five of the eight HAQ categories assess the function of the upper limbs.

Although the physical tests used in the present study are aimed at the elderly population, RA patients may present an early decrease in muscle strength, physical activity and balance in a pattern similar to that of elderly individuals, anticipating the risks resulting from the aging process. This may explain the finding that performance on physical tests was correlated with age: the older the patient, the poorer the physical performance. Although the four physical tests were significantly correlated among themselves, no significant association was found between any of the tests and the occurrence of falls. While some studies found an association between poorer performance on physical tests and a greater occurrence of falls or risk of falling, others found no such association [6, 11, 12, 16, 19, 36, 37]. The lack of standardization in the choice of tests for the RA population may be an important factor to be considered when analyzing these results, a gap that was observed by Santana et al. [41].

Several studies suggest that prospective studies be conducted to minimize memory bias [13-15, 19]. Cummings et al. [42], in a prospective, 12-month study of the elderly, found that $13-32 \%$ of the participants who fell did not report the episode at the end of the evaluation period. The follow-up strategies used were calendars, journals, fall log cards and self-reports to the researcher at the time of the fall. The present study has a methodological advantage, as it obtained the information quarterly by telephone, which improved the reliability of the report of falls and facilitated detailed clarification regarding the characteristics $[4-8,36]$.

\section{Conclusions}

The occurrence of falls in RA patients is high and is associated with a previous history of falls and polypharmacy, showing no association with disease activity or duration, functional capacity, physical performance, age or gender. In addition, the performances in the physical tests were associated with each other, and a poorer physical condition was related to greater disease activity, poorer functional capacity and older age.

\section{Funding}

A Master's degree fellowship from Coordenação de Aperfeiçoamento de Pessoal de Nível Superior (CAPES).

\section{Authors' contributions}

The rheumatologist (MRA) confirmed the RA diagnosis and performed the measurements to assess disease activity, and the nurse (FVBOC) collected the blood samples. Next, the anthropometric data were measured, and the functional questionnaires and physical tests were applied by the nurse and the physical therapist (MAL). All authors read and approved the final manuscript.
Ethics approval and consent to participate

The study was approved by the Research Ethics Committee of the Marília School of Medicine, protocol CAAE: 22845513.3.0000.5413. All participants signed the informed consent form.

\section{Consent for publication \\ Not applicable.}

\section{Competing interests}

The authors declare that they have no competing interests

\section{Publisher's Note}

Springer Nature remains neutral with regard to jurisdictional claims in published maps and institutional affiliations.

Received: 14 May 2018 Accepted: 13 July 2018

Published online: 27 July 2018

\section{References}

1. Pinho TAM, Silva AO, Tura LFR, Moreira MASP, Gurgel SN, Smith AAF, et al. Avaliação do risco de quedas em idosos atendidos em Unidade Básica de Saúde. Rev Esc Enferm USP. 2012;46(2):320-7.

2. Sandoval RA, Sá ACAM, Menezes RL, Nakatani AYK, Bachion MM. Ocorrência de quedas em idosos não institucionalizados : revisão sistemática da literatura. Rev Bras Geriatr Gerontol. 2013;16(4):855-63.

3. Oliveira AS, Trevizan PF, Bestetti MLT, Melo RC. Fatores ambientais e risco de quedas em idosos: revisão sistemática. Rev Bras Geriatr Gerontol. 2014;17(3): 637-45.

4. Smulders E, Schreven C, Weerdesteyn V, van den Hoogen FHJ, Laan R, Van Lankveld W. Fall incidence and fall risk factors in people with rheumatoid arthritis. Ann Rheum Dis. 2009 [cited 2013 may 23];68(11):1795-1796. Available from: http://www.ncbi.nlm.nih.gov/pubmed/19822719.

5. Stanmore EK, Oldham J, Skelton DA, O'Neill T, Pilling M, Campbell AJ, et al. Fall incidence and outcomes of falls in a prospective study of adults with rheumatoid arthritis. Arthritis Care Res (Hoboken). 2013;65(5):737-44.

6. Hayashibara M, Hagino H, Katagiri H, Okano T, Okada J, Teshima R. Incidence and risk factors of falling in ambulatory patients with rheumatoid arthritis: a prospective 1-year study. Osteoporos Int. 2010 [cited 2013 may 23];21(11):1825-33. Available from: http://www.ncbi.nlm.nih.gov/pubmed/ 20119662

7. Bugdayci D, Paker N, Rezvani A, Kesiktas N, Yilmaz O, Sahin M, et al. Frequency and predictors for falls in the ambulatory patients with rheumatoid arthritis: a longitudinal prospective study. Rheumatol Int. 2013 Apr:33(10):2523-7.

8. Brenton-Rule A, Dalbeth N, Bassett S, Menz HB, Rome K. The incidence and risk factors for falls in adults with rheumatoid arthritis: a systematic review. Semin Arthritis Rheum. 2015;44:389-98.

9. Kaz Kaz H, Johnson D, Kerry S, Chinappen U, Tweed K, Patel S. Fall-related risk factors and osteoporosis in women with rheumatoid arthritis. Rheumatology (Oxford). 2004;43(10):1267-71. Available from: https:// academic.oup.com/rheumatology/article-lookup/doi/10.1093/rheumatology/ keh304

10. Pereira IA, Mota LMH, Cruz BA, Brenol CV, Fronza LSR, Bertolo MB, et al. Consenso 2012 da Sociedade Brasileira de Reumatologia sobre o manejo de comorbidades em pacientes com artrite reumatoide. Rev Bras Reum. 2012; 52(4):474-95.

11. Duyurçakit B, Nacir B, Erdem HR, Karagoz A, Saraçoglu M. Fear of falling, fall risk and disability in patients with rheumatoid arthritis. Turk J Rheumatol. 2011:26(3):217-25.

12. Böhler C, Radner H, Ernst M, Binder A, Stamm T, Aletaha D, et al. Rheumatoid arthritis and falls: the influence of disease activity. Rheumatology (Oxford). 2012 [cited 2013 may 23];51 (11):2051-2057. Available from: http://www.ncbi.nlm.nih.gov/pubmed/22879462.

13. Marques WV, Cruz VA, Rêgo J, Silva NA. Influência da capacidade funcional no risco de quedas em adultos com artrite reumatoide. Rev Bras Reum. 2014;54(5):404-8.

14. Fessel KD, Nevitt MC. Correlates of fear of falling and activity limitation among persons with rheumatoid arthritis. Arthritis Care Res. 1997;10(4): 222-8.

15. Armstrong C, Swarbrick CM, Pye SR, O'Neill TW. Occurrence and risk factors for falls in rheumatoid arthritis. Ann Rheum Dis. 2005;64(11):1602-4. 
16. Jamison M, Neuberger GB, Miller PA. Correlates of falls and fear of falling among adults with rheumatoid arthritis. Arthritis Care Res (Hoboken). 2003; 49(5):673-80.

17. Schober HC, Maass K, Maass C, Reisinger EC, Schröder G, Kneitz C. Value of fall-risk tests for patients with rheumatoid arthritis. Z Rheumatol. 2011;70(7): 609-14.

18. Sugioka $Y$, Koike T. Fall risk and fracture. Associated factors for falls in patients with inflammatory polyarthritis. Clin Calcium. 2013;23(5):701-5.

19. Lourenço MA, Roma I, Assis MR. Ocorrência de quedas e sua associação com testes físicos, capacidade funcional e aspectos clínicos e demográficos em pacientes com artrite reumatoide. Rev Bras Reum. 2017;57(3):217-23.

20. Lourenço MA, Roma I, Assis MR. Correlação entre instrumentos de avaliação da funcionalidade e equilíbrio em pacientes com artrite reumatoide. Rev Bras Educ Fís Esporte. 2015;29(3):345-53.

21. Da Mota LMH, Cruz BA, Brenol CV, Pereira IA, Fronza LSR, Bertolo MB, et al. Consenso da Sociedade Brasileira de Reumatologia 2011 para o diagnóstico e avaliação inicial da artrite reumatoide. Rev Bras Reumatol. 2011;51(3):207-19.

22. Bruce B, Fries JF. The Health Assessment Questionnaire (HAQ). Clin Exp Rheumatol. 2005;23(5 SUPPL. 39):S14-8.

23. Ferraz MB, Oliveira LM, Araujo PMP, Atra E, Tugwell P. Crosscultural reliability of the physical ability dimension of the health assessment questionnaire. J Rheumatol. 1990 Jun;17(6):813-7.

24. Figueiredo KMOB, Lima KC, Guerra RO. Instrumentos de avaliação do equilíbrio corporal em idosos. Rev Bras Cineantropom Desempenho Hum. 2007;9(4):408-13.

25. Pimentel RM, Scheicher ME. Comparação do risco de queda em idosos sedentários e ativos por meio da escala de equilíbrio de Berg. Fisioter Pesq. 2009;16(1):6-10.

26. Miyamoto ST, Lombardi Junior I, Berg KO, Ramos LR, Natour J. Brazilian version of the Berg balance scale. Braz J Med Biol Res. 2004 Sep;37(9):141121. Available from: https://www.ncbi.n/m.nih.gov/pubmed/15334208.

27. Berg KO, Maki BE, Williams Jl, Holliday PJ, Wood-Dauphinee SL. Clinical and laboratory measures of postural balance in an elderly population. Arch Phys Med Rehabil. 1992;73(11):1073-80.

28. Nakano MM, Diogo MJDe, Jacob Filho W. Versão brasileira da Short Physical Performance Battery - SPPB: adaptação cultural e estudo da confiabilidade. UNICAMP; 2007.

29. Sayers SP, Jette AM, Haley SM, Heeren TC, Guralnick JM, Fielding RA. Validation of thelate-life function and disability instrument. J Am Geriatr Soc. 2004;52(9):1554-9.

30. Guimarães LHCT, Galdino DCA, Martins FLM, Vitorino DFM, Pereira KL, Carvalho EM. Comparação da propensão de quedas entre idosos que praticam atividade física e idosos sedentários. Rev Neurociências. 2004;12(2): 68-72.

31. Shumway-Cook A, Brauer S, Woollacott M. Predicting the probability for falls in community-dwelling older adults using the timed up \& go test. Phys Ther. 2000;80(9):896-903.

32. Podsiadlo D, Richardson S. The timed "Up \& Go": a test of basic functional mobility for frail elderly persons. J Am Geriatr Soc [Internet]. 1991 Feb;39(2): 142-8. Available from: http://www.ncbi.n/m.nih.gov/pubmed/1991946.

33. Cipriano Junior G, Yuri D, Bernardelli GF, Mair V, Buffolo E, Branco JNR. Avaliação da Segurança do Teste de Caminhada dos 6 Minutos em Pacientes no Pré-Transplante Cardíaco. Arq Bras Cardiol. 2009;92(4):312-9.

34. Rondelli R, Oliveira A, Corso SD, Malaguti C. Uma atualização e proposta de padronização do teste de caminhada de seis minutos. Fisioter Mov. 2009; 22(2):249-59.

35. Oswald AE, Pye SR, O'Neill TW, Bunn D, Gaffney K, Marshall T, et al. Prevalence and associated factors for falls in women with established inflammatory polyarthritis. J Rheumatol. 2006 Apr;33(4):690-4. Available from: http://www.ncbi.n/m.nih.gov/pubmed/16482644.

36. Stanmore EK, Oldham J, Skelton D a, O’Neill T, Pilling M, Campbell a J, et al. Risk factors for falls in adults with rheumatoid arthritis: A prospective study. Arthritis Care Res (Hoboken). 2013 Feb;

37. Metlı NB, Kurtaran A, Akyüz M. Impaired balance and fall risk in rheumatoid arthritis patients. Turk J Phys Med Rehab. 2015;61:344-51.

38. Robbins AS, Rubenstein LZ, Josephson KR, Schulman BL, Osterweil D, Fine G. Predictors of falls among elderly people. Results of two population-based studies. Arch Intern Med. 1989;149:1628-33.

39. Furuya T, Yamagiwa K, Ikai T, Inoue E, Taniguchi A, Momohara S, et al. Associated factors for falls and fear of falling in Japanese patients with rheumatoid arthritis. Clin Rheumatol. 2009 Nov [cited 2013 may 23];28(11): 1325-30. Available from: http://www.ncbi.nlm.nih.gov/pubmed/19618097.

40. Koerich J, Armanini KK, lop RR, Borges Júnior NG, Domenech SC, Gevaerd MS. Avaliação do equilíbrio corporal de pacientes com artrite reumatoide. Fisioter e Pesq. 2013;20(4):336-42

41. De Santana FS, Nascimento DDC, De Freitas JPM, Miranda RF, Muniz LF, Santos Neto L, et al. Avaliação da capacidade funcional em pacientes com artrite reumatoide: implicações para a recomendação de exercícios físicos. Rev Bras Reumatol [Internet]. 2014;4(5):378-85. Available from: http://www. sciencedirect.com/science/article/pii/S0482500414001144

42. Cummings SR, Nevitt MC, Kidd S. Forgetting falls. The limited accuracy of recall of falls in the elderly. J Am Geriatr Soc. 1988;36(7):613-6.
Ready to submit your research? Choose BMC and benefit from:

- fast, convenient online submission

- thorough peer review by experienced researchers in your field

- rapid publication on acceptance

- support for research data, including large and complex data types

- gold Open Access which fosters wider collaboration and increased citations

- maximum visibility for your research: over $100 \mathrm{M}$ website views per year

At $\mathrm{BMC}$, research is always in progress.

Learn more biomedcentral.com/submissions 